\title{
Intercept of Financial, Economic and Educational Transformations: Bibliometric Analysis
}

http://doi.org/10.21272/fmir.5(2).120-129.2021

Vladislav Novikov, ORCID: https://orcid.org/0000-0002-4979-2438

$\mathrm{PhD}$ researcher, Sumy State University, Sumy, Ukraine

\begin{abstract}
Financial, economic and educational transformations might be clarified from very different perspectives. Economic transformations are used to identify as changes in value added contribution of some branch in its formation at national level, or its productivity. Nowadays economic transformation are by far wider and more complicated process because of intensification of globalization, integration and digitalization of economic relationship over the last few decades. Financial transformations are also caused by intensification of globalization, integration and digitalization of economic relationship and might be identified through characteristics of the scale of financialization in curtain country and all over the world. Expansion of financialization and digitalization trends led to relevant changes in financial products characteristics, ways of its distribution and promotion, and general relevance of financial sector in macroeconomic stability and sustainable economic growth. Digitalization and COVID-19 pandemic also led to considerable challenges and transformation of education system. Education process are needed to be based on modern pedagogical, technological and scientific approaches. It became crucial to not only disseminate traditional knowledge and ensure of obtaining hard skills, but also make students enriched with soft skills. Traditional learning process accompanied with physical visiting of classes and writing a thesis are no more relevant, so e-learning and distance learning technologies are an integral part of educational process nowadays. It is became obvious that economic, financial and education transformation are connected somehow and converged but there is lack of researches aimed at specification of their intercept and cohesion. Therefore, this research aimed at clarification of intercept between financial, economic and education transformations has both theoretical value and might have practical implication for policymakers. It is realized using VOSviewer tool based on publications in Scopus on financial, educational and economic transformations 1990-2020. Therefore, bibliometric analysis allow concluding that there are both common and specific clusters of scientific researches on economic, financial and educational transformations. Namely, all three types of transformations are somehow dependent on health care system, environmental determinants, social aspects, etc. It can be pointed out that these transformations have common preconditions, consequences and ways of implementation. This may leads to conclusion that there are some convergence between educational, financial and economic transformations.
\end{abstract}

Keywords: bibliometric analysis, digitalization, economic transformations, educational transformations, financial transformations.

JEL Classification D83, L20, N70, O14, F52.

Cite as: Novikov, V. (2020). Intercept of Financial, Economic and Educational Transformations: Bibliometric Analysis. Financial Markets, Institutions and Risks, 5(2), 120-129. http://doi.org/10.21272/fmir.5(2).120$\underline{129.2021}$

Received: 2 May,2021

Accepted: 6 June, 2021

Published: 25 June, 2021

Copyright: (C) 2021 by the author. Licensee Sumy State University, Ukraine. This article is an open access article Copyright: (C) 2021 by the author. Licensee Sumy State University, Ukraine. This article is an open access article
distributed under the terms and conditions of the Creative Commons Attribution (CC BY) license (https://creativecommons.org/licenses/by/4.0/)

\section{Introduction}

Financial, economic and educational transformations might be clarified from very different perspectives. Basically economic transformations are used to identify as changes in value added contribution of some branch in its formation at national level. Consequently, this process covered a shift of importance from agriculture to industry and then to the sphere of services. It is also important in terms of clarifying specific features of economic transformations' trends to point out peculiarities of changes in detailed branch structure 
Financial Markets, Institutions and Risks, Volume 5, Issue 2, 2021 ISSN (online) - 2521-1242 ISSN (print) - 2521-1250

(understanding of not only importance for creation of country value added of industry, agriculture of sphere of service, but also importance of a curtain branch within these three sectors of economy). At the later stages of economic development, changes in productivity and labor force dissemination within and between different branches began to consider as one of the kinds of economic transformations. Nowadays economic transformation are by far wider and more complicated process because of intensification of globalization, integration and digitalization of economic relationship over the last few decades. Therefore, in modern conditions to ensure sustainable economic development it is necessary to pay attention to a much wider range of issues and processes than earlier, including spatial distribution (urbanization, settlement structure, etc.), demographic movement, changes in sectoral structure, improving infrastructure and superstructures, etc., which should accompany the increase in productivity caused by structural changes.

Basically, financial transformations are also caused by intensification of globalization, integration and digitalization of economic relationship and might be identified through characteristics of the scale of financialization in curtain country and all over the world. Expansion of financialization and digitalization trends led to relevant changes in financial products characteristics, ways of its distribution and promotion, and general relevance of financial sector in macroeconomic stability and sustainable economic growth. Moreover, digitalization and COVID-19 pandemic also led to considerable challenges and transformation of education system. Education process are needed to be based on modern pedagogical, technological and scientific approaches. It became crucial to not only disseminate traditional knowledge and ensure of obtaining hard skills, but also make students enriched with soft skills. Traditional learning process accompanied with physical visiting of classes and writing a thesis are no more relevant, so e-learning and distance learning technologies are an integral part of educational process nowadays. It should be noted that it is became obvious that economic, financial and education transformation are connected somehow and converged but there is lack of researches aimed at specification of their intercept and cohesion. Therefore, this research aimed at clarification of intercept between financial, economic and education transformations has both theoretical value and might have practical implication for policymakers.

Literature review. In term of characteristics of financial transformation, it should be noted that in general it concerns to strategical changes in different segment of financial system separately.

Didenko and Sidelnyk (2021) characterized financial transformation through changes in insurance market. Under the empirical research results authors concluded that there is a connection between economic development and insurance market development. It is found out that a number of Asian countries (China, Singapore, Taiwan, Thailand), which are showing rapid economic development, are gradually beginning to occupy a leading position among research in the field of insurance. Moreover, authors also pointed out that there are some considerable transformations inside insurance market, which are caused by digitalization, globalization, and convergence of financial sector segments.

In turn, Yelnikova and Golochalova (2020) focused on clarification of cohesion between financial transformations and social effects. Authors mentioned that over the last few decades there are appeared new instruments on security market. One of such instruments are social bonds. Under the bibliometric analysis it was highlighted that social bonds might boost economic, environmental and social transformations.

Kaya (2020) researched financial transformations under some macroeconomic circumstance, i. e. focused on relationships between financial and economic transformations. In general, the results of empirical study allow concluding that middle- and low-income countries are more vulnerable to the expected economic and financial crisis than high-income countries because their financial markets are underdeveloped. Progress in economic transformations triggered financial ones. On the other hand, high-income countries are more vulnerable when the country's central bank uses their assets to protect its system. Empirical assessments have confirmed that non-OECD countries are more vulnerable than OECD member countries, as in most respects their markets are less developed; at the same time, OECD member countries are weaker in terms of their stock markets and the amount of debt securities held in investment portfolios.

Molotok (2020) pointed out also one more important vector of financial transformations. He highlighted that nowadays activity of central and sub-central governments (especially, in terms of fiscal policy realization and budget process) might be as transparent as possible. Lack of budget transparency results in absence of loyalty and trust to government. Otherwise, transparent budget planning and realization leads to citizens' trust and inclusion.

Eddassi (2020) researched relationships between fiscal transformations and natural resources. According to the results of the study, he proposed a set of countercyclical measures of fiscal policy, which relate to changes 
in the volume of public procurement, remuneration of civil servants, the volume of public capital investments, tax rates, etc. Author emphasized the need to structural transformation of budget revenues by increasing the share of tax revenues and reducing the share of revenues from rent for the use of the country's subsoil.

Frederick and Kasztelnik (2020) combine research of transformations in financial and educational spheres. Authors deeply analysed past and current trends in development of higher educational institutions in The United States of America and developed some forecasts of its future perspectives. Specifically, among possible educational transformations in the United States of America they pointed out as follows:

$>$ narrowing of the amount of higher educational institutions in nearest five years;

$>$ necessity of inclusion, administration and professors loyalty to disabled students, students - representatives of national minorities, etc. might become a precondition of success, efficiency and competitiveness of higher educational institution;

$>$ online education movement and e-learning technologies are becoming a new trend and forcing significant transformation of the whole educational process;

$>$ being on top of the world university rankings become very important, especially from financial performance perspective (heading the ranking allow gaining students and parents loyalty, point higher payment for education, etc.).

Considering all the above-mentioned, authors agreed that as a rule bigger university means better financial performance. Therefore, merges and acquisitions might become one of the possible tools of survival of higher educational institutions in severe competition in future.

Matos and Kasztelnik (2021) also paid their attention to educational transformations in the United States of America. Authors researched on how academic leadership might influence transformation of e-learning technologies. They pointed out that in modern conditions academicians might develop soft-skills that would help them to ensure efficient studying process via online platforms. They highlighted that digitalization of education will disseminate and higher educational institutions might adapt to these new challenges in order to survive.

Kasztelnik and Brown (2020) also researched relationships between transformations of innovative leadership patterns and socio-economic transformations. They argued that formation of leadership competencies of public administration officials and its active development leads to improved efficiency of managerial actions, improvement of public relations.

\section{Methodology and Results}

Thus, the aim of the research is to clarify intercept between financial, economic and educational transformations via bibliometric analysis too. Specifically, it is analyzed using VOSviewer contextual clusters of publications in Scopus on the three above-mentioned topics for 1990-2020 and identified common research direction that might led to the conclusion about familiar preconditions and consequences of financial, economic and educational transformations.

The dynamic of publications in Scopus on relevant topics is on Figure 1.

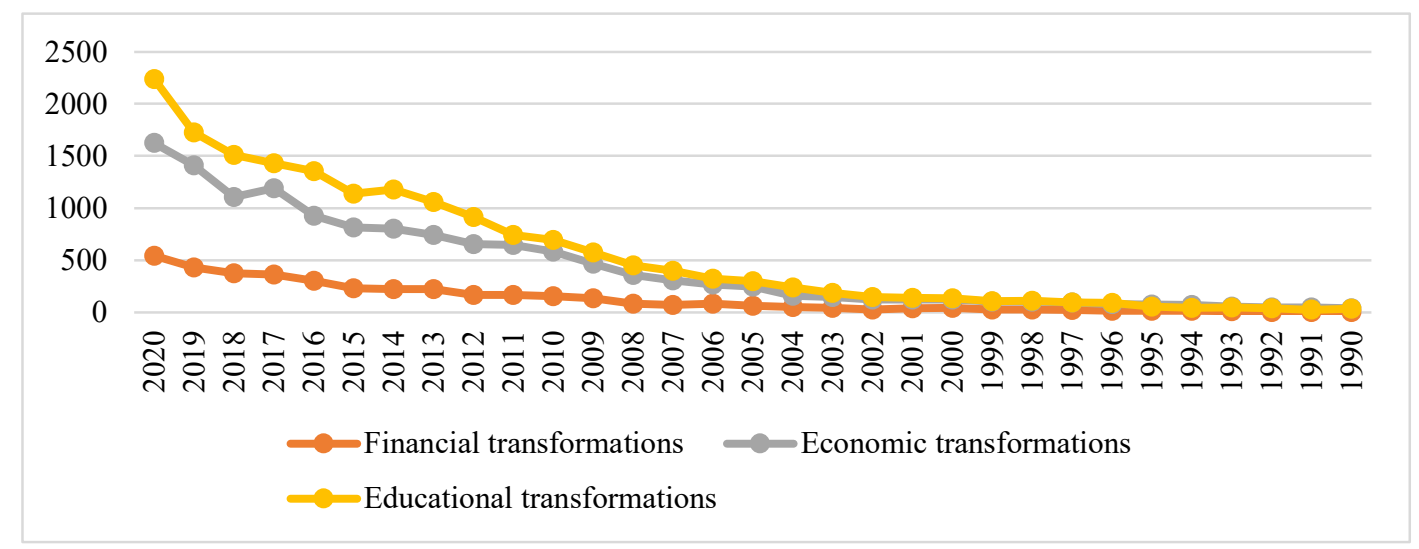

Figure 1. The dynamic of Scopus publication on financial, economic and educational transformations in 1990-2020, amount of articles Source: Scopus, 2021. 
Therefore, it can be concluded that financial transformation issues are less popular among researchers. Amount of publications on the relevant topic began considerably increase after the global financial crisis of 2007-2009 that brought to the conclusion that this crisis triggered transformational processes in financial sector. Trends of economic transformation and educational ones are very close to each other with a small dominance of the last ones. It can be considered that a boost of scientific attention to economic and educational transformations began to gradually grow from 2004. The most cited Scopus publications on financial, economic and educational transformations in 1990-2020 are presented in Table 1. As far as can be seen from the Table 1, most of the publications are cross-disciplinary, i. e. focused on the research of mutual impact of different kinds of transformations.

Table 1. Top 5 most cited publications in Scopus on financial, economic and educational transformations in 1990-2020 (Scopus, 2021)

\begin{tabular}{|c|c|c|c|c|c|}
\hline № & Publication title & Authors & Year & Source & $\begin{array}{c}\text { Number of } \\
\text { citations }\end{array}$ \\
\hline \multicolumn{6}{|c|}{ Financial transformations } \\
\hline 1 & The econometrics of financial markets & $\begin{array}{l}\text { Campbell, J.Y., } \\
\text { Lo, A.W., } \\
\text { MacKinlay, A.C. }\end{array}$ & 2012 & $\begin{array}{l}\text { The Econometrics of Financial } \\
\text { Markets } \\
\text { pp. 1-611 }\end{array}$ & 2619 \\
\hline 2 & $\begin{array}{l}\text { Quantitative risk management: Concepts, techniques, and } \\
\text { tools }\end{array}$ & $\begin{array}{l}\text { McNeil, A.J., } \\
\text { Frey, R., } \\
\text { Embrechts, P. }\end{array}$ & 2005 & $\begin{array}{l}\text { Quantitative Risk Management: } \\
\text { Concepts, Techniques, and Tools }\end{array}$ & 1794 \\
\hline 3 & Law, finance, and economic growth in China & $\begin{array}{l}\text { Allen, F., } \\
\text { Qian, J., } \\
\text { Qian, M. }\end{array}$ & 2005 & $\begin{array}{l}\text { Journal of Financial Economics } \\
77(1), \text { pp. } 57-116\end{array}$ & 1596 \\
\hline 4 & $\begin{array}{l}\text { The economics of small business finance: The roles of } \\
\text { private equity and debt markets in the financial growth cycle }\end{array}$ & N. Berger, A., F. Udell, G. & 1998 & $\begin{array}{l}\text { Journal of Banking and Finance } \\
22(6-8) \text {, pp. 613-673 }\end{array}$ & 1449 \\
\hline 5 & Analysis of financial time series & Tsay, R.S. & 2010 & $\begin{array}{l}\text { Analysis of Financial Time Series } \\
\text { pp. 1-677 }\end{array}$ & 853 \\
\hline \multicolumn{6}{|c|}{ Economic transformations } \\
\hline 1 & The economics of climate change: & Stern, N. & 2007 & $\begin{array}{l}\text { The Economics of Climate Change: } \\
\text { The Stern Review } \\
9780521877251 \text {, pp. } 1-692 \\
\end{array}$ & 5334 \\
\hline 2 & $\begin{array}{l}\text { Explicating dynamic capabilities: The nature and } \\
\text { microfoundations of (sustainable) enterprise performance }\end{array}$ & Teece, D.J. & 2007 & $\begin{array}{l}\text { Strategic Management Journal } \\
\text { 28(13), pp. 1319-1350 }\end{array}$ & 4792 \\
\hline 3 & $\begin{array}{l}\text { Technological transitions as evolutionary reconfiguration } \\
\text { processes: A multi-level perspective and a case-study }\end{array}$ & Geels, F.W. & 2002 & $\begin{array}{c}\text { Research Policy } \\
\text { 31(8-9), pp. 1257-1274 }\end{array}$ & 2682 \\
\hline 4 & Strategy in emerging economies & $\begin{array}{l}\text { Hoskisson, R.E., } \\
\text { Eden, L., } \\
\text { Lau, C.M., } \\
\text { Wright, M. } \\
\end{array}$ & 2000 & $\begin{array}{l}\text { Academy of Management Journal } \\
43(3) \text {, pp. } 249-267\end{array}$ & 2343 \\
\hline 5 & Economics and identity & $\begin{array}{l}\text { Akerlof, G.A., } \\
\text { Kranton, R.E. }\end{array}$ & 2000 & $\begin{array}{l}\text { Quarterly Journal of Economics } \\
115(3), \text { pp. } 715-753\end{array}$ & 2077 \\
\hline \multicolumn{6}{|c|}{ Educational transformations } \\
\hline 1 & Punishment and inequality in America & $\begin{array}{c}\text { Western, B., } \\
\text { Lopoo, L., Pettit, B. }\end{array}$ & 2006 & $\begin{array}{l}\text { Punishment and inequality in } \\
\text { America } \\
\text { pp. } 1-247\end{array}$ & 1459 \\
\hline 2 & Socioeconomic inequalities in depression: A meta-analysis & $\begin{array}{l}\text { Lorant, V., } \\
\text { Deliège, D., } \\
\text { Eaton, W., (...), } \\
\text { Philippot, P., } \\
\text { Ansseau, M. } \\
\end{array}$ & 2003 & $\begin{array}{l}\text { American Journal of Epidemiology } \\
157(2), \text { pp. } 98-112\end{array}$ & 1378 \\
\hline 3 & $\begin{array}{l}\text { Enhancing School-Based Prevention and Youth } \\
\text { Development Through Coordinated Social, Emotional, and } \\
\text { Academic Learning }\end{array}$ & $\begin{array}{l}\text { Greenberg, M.T., } \\
\text { Weissberg, R.P., } \\
\text { O'Brien, M.U., (...), } \\
\text { Resnik, H., } \\
\text { Elias, M.J. }\end{array}$ & 2003 & $\begin{array}{l}\text { American Psychologist } \\
\text { 58(6-7), pp. 466-474 }\end{array}$ & 995 \\
\hline 4 & Globalizing education policy & Rizvi, F., Lingard, B. & 2009 & $\begin{array}{l}\text { Globalizing Education Policy } \\
\text { pp. } 1-228\end{array}$ & 971 \\
\hline 5 & Job resources buffer the impact of job demands on burnout & $\begin{array}{l}\text { Bakker, A.B., } \\
\text { Demerouti, E., } \\
\text { Euwema, M.C. }\end{array}$ & 2005 & $\begin{array}{c}\text { Journal of Occupational Health } \\
\text { Psychology } \\
\text { 10(2), pp. 170-180 } \\
\end{array}$ & 932 \\
\hline
\end{tabular}

Source: Scopus, 2021.

Figure 2 (see in Appendix) demonstrates co-occurrence bibliometric matrix on economic transformations.

Considering results of bibliometric analysis based o Scopus publications on economic transformations it might be pointed out existence of 5 contextual clusters of researches dedicated to different perspectives relevant topic, specifically: 
$>$ red cluster (187 items) covers papers aimed at identification of relationships between economic transformations and health care system and social conditions (poverty, urban development, gender aspects, demographical characteristics, educational status, migration trends, cultural patterns, etc.);

$>$ green cluster (160 items) consists of papers focused on clarification of two-way relationships between economic transformations and environmental determinants, traditional and renewable energy production and consumption, innovation and technological change, etc.;

$>$ dark blue cluster (137 items) includes publications dedicated to economic transformations caused by agriculture sector development, food security issues and biodiversity;

$>$ yellow cluster (124 items) covers publications on economic transformations and biofuel production and consumption, chemistry fertilizers usage, water supply management, etc.;

$>$ light blue cluster (117 items) consists of papers focused on clarification of cohesion between economic transformations and waste management;

$>$ violet cluster (97 items) covers papers aimed at analysis of economic transformations and regional (rural and urban) development.

Figure 3 (see in Appendix) demonstrates co-occurrence bibliometric matrix on financial transformations.

Under the analysis of contextual peculiarities of the researches dedicated to financial transformations issues, there might be underlined several clusters:

- $\quad$ red cluster (155 items) covers papers aimed at identification of relationships between financial transformations and corporate management, risk management, information management, etc.;

- $\quad$ green cluster (142 items) consists of papers focused on clarification of relationships between financial transformations and behavioral aspects, social factors, institutional precondition, investment policy, property and land markets, competitiveness, etc.;

- $\quad$ dark blue cluster (102 items) includes publications dedicated to financial transformations and corporate governance, financial crisis, banking activity, etc.;

- yellow cluster (80 items) covers publications on financial transformations and health care system, social and educational aspects, rural development, etc.;

- violet cluster (70 items) covers papers aimed at analysis of financial transformations and environmental issues.

Figure 4 (see in Appendix) demonstrates co-occurrence bibliometric matrix on educational transformations.

Considering results of bibliometric analysis based o Scopus publications on educational transformations, there might be underlined several clusters:

$>$ red cluster (224 items) covers papers aimed at clarification of educational transformation under cultural changes, decentralization, democratization, gender aspects, globalization and inclusion, etc.;

$>$ green cluster (179 items) covers papers dedicated to educational transformation as a part of health care system;

$>$ dark blue cluster (149 items) includes publications dedicated to educational transformations under economic, environmental, and social factors, etc.;

$>$ yellow cluster (68 items) covers publications on educational transformations in different cultural and national environments, etc.;

$>$ violet cluster (60 items) covers papers aimed at analysis of educational transformations caused by neurophysiologic, cognitive and mental factors.

\section{Conclusions, Discussion and Recommendations}

Therefore, bibliometric analysis allow concluding that there are both common and specific clusters of scientific researches on economic, financial and educational transformations. Namely, all three types of transformations 
are somehow dependent on health care system, environmental determinants, social aspects, etc. It can be pointed out that these transformations have common preconditions, consequences and ways of implementation. This may leads to conclusion that there are some convergence between educational, financial and economic transformations.

\section{Funding}

The article was published as part of a research projects "Convergence of economic and educational transformations in the digital society: modeling the impact on regional and national security" (No. 0121U109553) and "Reforming the lifelong learning system in Ukraine for the prevention of the labor emigration: a coopetition model of institutional partnership" (No. 0120U102001).

\section{References}

1. Akerlof, G. A., \& Kranton, R. E. (2000). Economics and identity. Quarterly Journal of Economics, 115(3), 715-753. [Link]

2. Allen, F., Qian, J., \& Qian, M. (2005). Law, finance, and economic growth in china. Journal of Financial Economics, 77(1), 57-116. [Google Scholar]

3. Bakker, A. B., Demerouti, E., \& Euwema, M. C. (2005). Job resources buffer the impact of job demands on burnout. Journal of Occupational Health Psychology, 10(2), 170-180. [Link]

4. Campbell, J. Y., Lo, A. W., \& MacKinlay, A. C. (2012). The econometrics of financial markets. The econometrics of financial markets, 1-611. [Google Scholar]

5. Didenko, I., Sidelnyk, N. (2021). Society's Readiness for Modern Challenges of the Insurance Market: Bibliometric Analysis. Financial Markets, Institutions and Risks, 5(1), 116-125. [CrossRef]

6. Eddassi, H. (2020). Fiscal Regime and Tax Policy in Resource-Rich Countries In The Process Of Globalization: Literature Review. SocioEconomic Challenges, 4(2), 67-77. [CrossRef]

7. Frederick, D. T., Kasztelnik, K. (2020). An Analytical Study of Impact of International Merger and Acquisitions on the Financial Performance for Higher Education Institution in the United States. Financial Markets, Institutions and Risks, 4(4), 5-30. [CrossRef]

8. Geels, F. W. (2002). Technological transitions as evolutionary reconfiguration processes: A multilevel perspective and a case-study. Research Policy, 31(8-9), 1257-1274. [CrossRef]

9. Greenberg, M. T., Weissberg, R. P., O'Brien, M. U., Zins, J. E., Fredericks, L., Resnik, H., \& Elias, M. J. (2003). Enhancing school-based prevention and youth development through coordinated social, emotional, and academic learning. American Psychologist, 58(6-7), 466-474. [Link]

10. Hoskisson, R. E., Eden, L., Lau, C. M., \& Wright, M. (2000). Strategy in emerging economies. Academy of Management Journal, 43(3), 249-267. [Link]

11. Kasztelnik, K., Brown, D. (2020). The Observational Socio-Economic Study and Impact on the International Innovative Leadership in the United States. SocioEconomic Challenges, 4(4), 6394. [CrossRef]

12. Kaya, H.D. (2020). The Depth of the Financial System: A Comparison of Developed and Less Developed Countries. Financial Markets, Institutions and Risks, 4(4), 109-118. [CrossRef]

13. Lorant, V., Deliège, D., Eaton, W., Robert, A., Philippot, P., \& Ansseau, M. (2003). Socioeconomic inequalities in depression: A meta-analysis. American Journal of Epidemiology, 157(2), 98-112. [Google $\underline{\text { Scholar] }}$

14. Matos, L., Kasztelnik, K. (2021). Transformational Educational Leadership and the Innovative Strategies Engaging Online Faculty for the Excellent Teaching Performance in the United States. Business Ethics and Leadership, 5(1), 6-21. [CrossRef]

15. McNeil, A. J., Frey, R., \& Embrechts, P. (2005). Quantitative risk management: Concepts, techniques, and tools. Quantitative risk management: Concepts, techniques, and tools. [CrossRef]

16. Molotok, I.F. (2020). Bibliometric and Trend Analysis of Budget Transparency. Business Ethics and Leadership, 4(2), 116-122. [CrossRef] 
17. N. Berger, A., \& F. Udell, G. (1998). The economics of small business finance: The roles of private equity and debt markets in the financial growth cycle. Journal of Banking and Finance, 22(6-8), 613-673. [Link]

18. Rizvi, F., \& Lingard, B. (2009). Globalizing education policy. Globalizing education policy, 1-228. [Link]

19. Scopus (2020). [Link]

20. Stern, N. (2007). The economics of climate change: The stern review. The economics of climate change: The stern review, 1-692. [Link]

21. Teece, D. J. (2007). Explicating dynamic capabilities: The nature and microfoundations of (sustainable) enterprise performance. Strategic Management Journal, 28(13), 1319-1350. [Link]

22. Tsay, R. S. (2010). Analysis of financial time series. Analysis of financial time series, 1-677. [Link]

23. VOSviewer (2020). [Link]

24. Western, B., Lopoo, L., \& Pettit, B. (2006). Punishment and inequality in america. Punishment and inequality in America, 1-247. [Link]

25. Yelnikova, Y., Golochalova, I. (2020). Social Bonds as an Instrument of Responsible Investment. Financial Markets, Institutions and Risks, 4(4), 119-128. [CrossRef] 


\section{Appendix}

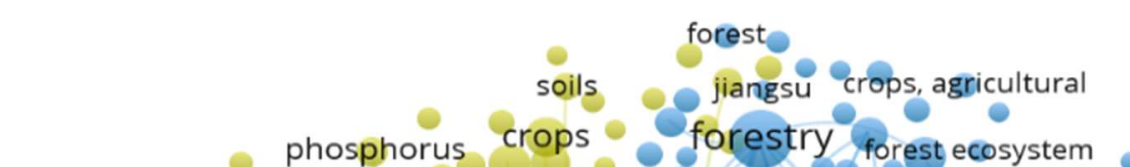
microalgae cultivation conservation nutrition

hydrogen water quality cultivation land use ecosystem

biofuels chemistry land use ecosystem
population growth animals fishery

refining bioenergy water supply farming system cities socioeconomic factors emigration and immigration

- Oo mining urbanization food prevalence history

prevalence history migration

Biogas waste management environmental protection poland education culture sex difference

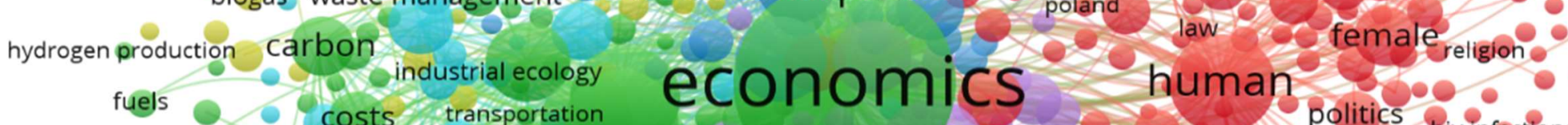
- politics hivinfections

regional planning political economy oconomy 30 healtheconomies

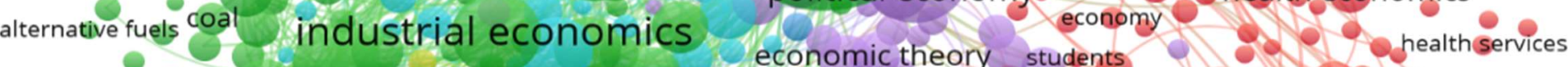

energy efficiency industry aralth care policy

economic growth social development health carecost

energy policy economic growth social development forecasting healthexpenditures

carbon emission

insurance, health

3 economic structure

energy intensity policy maker

Sosviewer

Figure 2. Results of VOSviewer network visualization on co-occurrence of publications on economic transformations in Scopus for 1990-2020

Source: VOSviewer, 2021 


\section{s VOSviewer}

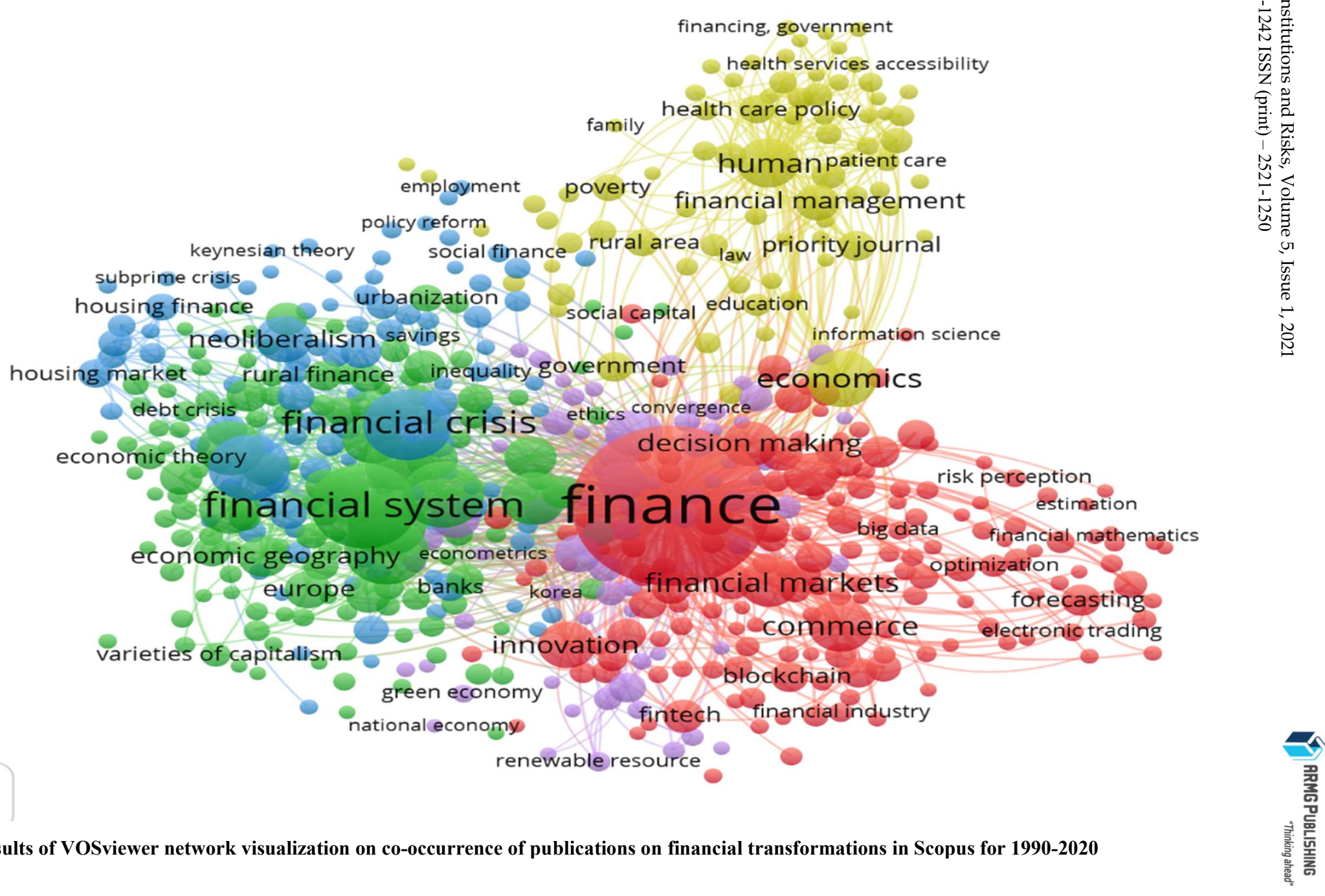


觔 VOSviewer

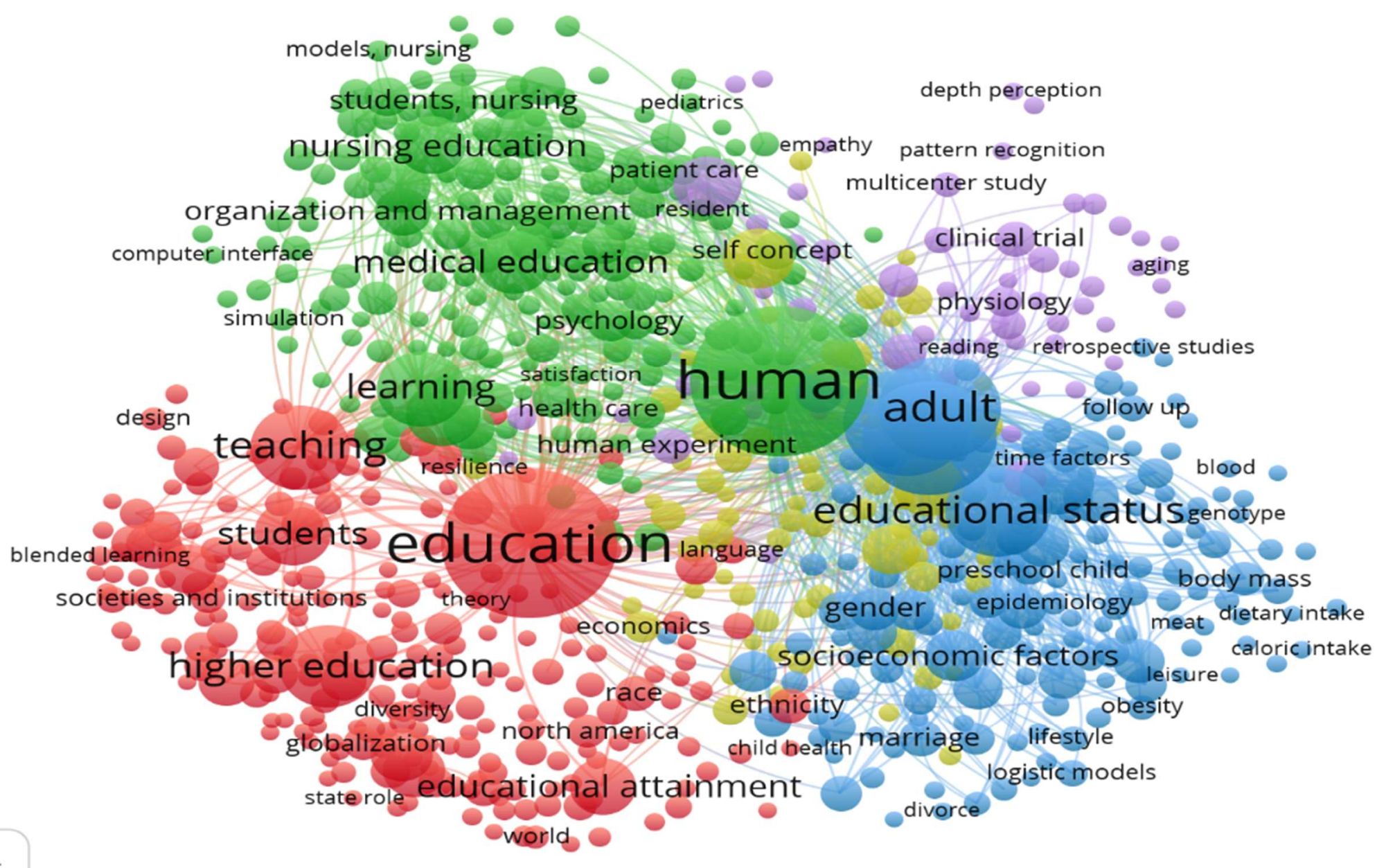

Figure 4. Results of VOSviewer network visualization on co-occurrence of publications on educational transformations in Scopus for 1990-2020 Source: VOSviewer, 2021 